1 CYP2D6 Genotyping for Personalized Therapy of Tamoxifen in Indonesian Women with ER+ Breast

\title{
2 Cancer
}

4 Baitha Palanggatan Maggadani ${ }^{1^{*}}$, Kathleen Irena Junusmin ${ }^{2 *}$, Levana L. Sani ${ }^{2}$, Caroline Mahendra ${ }^{2}$, 5 Margareta Amelia ${ }^{2}$, Gabriella ${ }^{2}$, Astrid Irwanto ${ }^{2,3}$, Harmita ${ }^{1}$, Yahdiana Harahap ${ }^{1,4}$, Samuel J. 6 Haryono $^{4,5+}$

$8 \quad{ }^{1}$ Faculty of Pharmacy, University of Indonesia, Jakarta, Indonesia

$9 \quad{ }^{2}$ Nalagenetics Pte Ltd, Singapore, Singapore

$10{ }^{3}$ Department of Pharmacy, Faculty of Science, National University of Singapore, Singapore, Singapore

$11{ }^{4}$ Indonesia Defense University, Bogor, West Java, Indonesia

$12{ }^{5}$ Surgical Oncology Division, SJH Initiative, MRCCC Siloam Hospital, Jakarta, Indonesia

13 *These authors contributed equally to this work.

$14{ }^{\dagger}$ Corresponding authors: samuelharyono@yahoo.com

\section{Abstract}

Tamoxifen is a Selective Estrogen-Receptor Modulator (SERM) commonly prescribed for standard of care in estrogen receptor positive $(E R+)$ breast cancer as an adjuvant therapy. Tamoxifen is metabolized by CYP2D6 into its active metabolite, endoxifen, which has been known to play an important role in reducing risk of ER+ breast cancer recurrence. CYP2D6 is a highly polymorphic gene with more than 100 alleles. The phenotype of this gene is categorized into ultrarapid metabolizer (UM), normal metabolizer (NM), intermediate metabolizer (IM), and poor metabolizer (PM). Certain CYP2D6 polymorphisms may cause reduced activity of this enzyme. Studies have found that reduced CYP2D6 activity in IM and PM patients causes low efficacy of standard tamoxifen therapy. This study aims to observe the distribution of CYP2D6 alleles and its correlation with endoxifen levels in Indonesian ER+ breast cancer patients. 151 patients who have received tamoxifen therapy for at least eight weeks were recruited prospectively. DNA and blood samples were collected with buccal swab and finger-prick methods, respectively. Genotyping was performed using the qPCR method while metabolite level measurement was performed using high performance liquid chromatography tandem mass spectrometry. We found that $40.67 \%$ of ER+ breast cancer patients recruited were IM. CYP2D6*10 was the most abundant allele $(0.288)$ in this population, and *10/*36 was the most frequently observed diplotype (0.236). Endoxifen levels between the NM-PM, NM-IM, and IM-PM were statistically significant ( $p$-value $=6.26 \times 10^{-5}, 9.12 \times 10^{-5}$, and $4.714 \times 10^{-3}$, respectively), and dose increase of tamoxifen to $40 \mathrm{mg}$ daily successfully increased endoxifen levels in IMs to a similar level with NMs at baseline. Given these findings, implementing pharmacogenomic testing of CYP2D6 on ER+ breast cancer women who are about to undergo tamoxifen therapy may be beneficial to increase the likelihood of achieving expected endoxifen levels, thus better treatment efficacy.

Keywords: CYP2D6 polymorphisms, endoxifen, pharmacogenomics, dose adjustment, allele frequency, phenotype distribution, metabolizer profile

\section{Introduction}


medRxiv preprint doi: https://doi.org/10.1101/2021.06.25.21259564; this version posted June 30, 2021. The copyright holder for this preprint (which was not certified by peer review) is the author/funder, who has granted medRxiv a license to display the preprint in perpetuity.

It is made available under a CC-BY 4.0 International license .

45

46

47

48

49

50

51

52

53

54

55

56

57

58

59

60

61

62

63

64

65

66

67

68

69

70

71

72

73

74

75

76

77

78

79

80

81

82

83

84

85

86

87

88

89
Estrogen receptor (ER) expression is the main indicator of potential responses to hormonal therapy, and approximately $70 \%$ of human breast cancers are hormone-dependent and ER+ (Lumachi et al., 2013). Hormone receptor-positive $B C$ is associated with less aggressive features and a better prognosis because of the benefits from currently available endocrine therapy (Li et al., 2020). Tamoxifen is the current standard of care for ER+ breast cancer adjuvant therapy. It works by binding to the estrogen receptor. The drug has been proven effective in reducing the number of recurrences especially in pre-menopausal women. About 170,000 tamoxifen prescriptions were filed in 2015 in Indonesia (IMS prescription data Indonesia, 2015), which implies that the usage of this drug has been prevalent in Indonesia to treat ER+ breast cancer.

Tamoxifen is a prodrug that needs to be metabolized to be active. However, half of the patients receiving tamoxifen may not have the full benefit of this drug due to the genetic polymorphisms that affect the function of the main enzyme metabolizing tamoxifen, CYP2D6 (Goetz et al., 2008). Tamoxifen is metabolized to 4-hydroxy- $N$-desmethyltamoxifen (endoxifen), which has been proven to be an important contributor to the overall anticancer effect. Endoxifen is formed predominantly by CYP2D6 from $\mathrm{N}$-desmethyltamoxifen, the most abundant metabolite (Dezentjé et al., 2009). Endoxifen threshold value has been discovered to significantly impact breast cancer survival rates (Goetz et al., 2005; Madlensky et al., 2011). Upon years of follow up, those with endoxifen levels lower than $5.97 \mathrm{ng} / \mathrm{mL}$ had a $30 \%$ higher chance of having recurrence of breast cancer. Madlensky et al. further showed that being a CYP2D6 poor/intermediate metabolizer was associated with having a higher Body Mass Index (BMI), and consequently lower tamoxifen concentrations predicted risk for breast cancer recurrence (Madlensky et al., 2011). Additionally, study has also shown that individual variability of CYP2D6 contributed $53 \%$ towards the ratio of $\mathrm{N}$-desmethyltamoxifen and endoxifen, while combined other CYPS genetic factors (CYP2C9, CYP2C19, CYP3A5) and non-genetic factors (age, $\mathrm{BMI}$ ) contributed to only $2.8 \%$ (Saladores et al., 2015).

CYP2D6 gene that encodes Cytochrome P450 2D6 (CYP2D6) enzyme has more than 100 variants; some causing reduced activity, and others causing complete loss of function. The spectrum of the CYP2D6 enzymatic activity translates to different metabolizer profiles that are grouped into normal, ultrarapid, extensive, intermediate, and poor metabolizers (NM, UM, EM, IM, and PM, respectively), depending on how many reducing and/or loss of function alleles an individual carries. Asians and Africans were known to have up to 50\% reduced activity alleles (Bradford, 2002). In Malays, Chinese and Indians, intermediate metabolizers occur in $35 \%, 45.38 \%$, and $15 \%$, respectively (Teh et al., 2001; Cui et al., 2020; Goh et al., 2017). Meanwhile, Caucasians were commonly extensive metabolizers (Chin et al., 2016). CYP2D6 ultra-rapid and extensive metabolizers are able to take tamoxifen as indicated, according to the guidelines by Clinical Pharmacogenetics Implementation Consortium (CPIC) (Goetz et al., 2018).

This study aims to observe the distribution of CYP2D6 genotypes and its correlation with endoxifen levels in ER+ breast cancer patients in Indonesia. CYP2D6 allele frequency and tamoxifen metabolite concentrations were observed. Patients who had CYP2D6 IM and PM phenotype profile were given recommendation to adjust tamoxifen dose to $40 \mathrm{mg}$ daily, while patients who were clinically ineligible for tamoxifen dose increase according to clinical guidelines were switched to aromatase inhibitor. Our study observed the effectiveness of adjusting tamoxifen dosage as the first line of 
medRxiv preprint doi: https://doi.org/10.1101/2021.06.25.21259564; this version posted June 30, 2021. The copyright holder for this preprint (which was not certified by peer review) is the author/funder, who has granted medRxiv a license to display the preprint in perpetuity.

It is made available under a CC-BY 4.0 International license .

90

91

92

93

94

95

96

97

98

99

100

101

102

103

104

105

106

107

108

109

110

111

112

113

114

115

116

117

118

119

120

121

122

123

124

125

126

127

128

129

130

131

132

133

134 action for patients who are clinically eligible to still consume the drug. Patients who received tamoxifen dose adjustment were monitored to ensure safety from potential side effects associated with tamoxifen.

\section{Materials and Methods}

\section{Ethics Approval}

Institutional Review Board (IRB) approval was granted by MRCCC Siloam Hospitals Semanggi Ethics Review Committee (Jakarta, Indonesia) under IRB Reference Number 001/EA/KEPKK/RSMRCCC/V/2019.

\section{Study Participants}

Patients were recruited from SJH Initiative, MRCCC Siloam Hospital Jakarta, Indonesia, from October 2019 to April 2021 ( $n=151$ ). The inclusion criteria of this study were as follows: (1) patient was diagnosed with ER+ breast cancer and (2) had consumed tamoxifen for at least eight weeks. Patients who fulfilled the inclusion criteria were offered to participate in the study and informed consent was obtained. Flow of recruitment steps is shown in Fig.1. Ethnicities reported in this study were selfreported, participants who identified with two or more ethnicities were categorized as mixed races.

\section{DNA Extraction}

Buccal swab sample was obtained from the patient for CYP2D6 genotyping using ORAcollect•DNA OCR-100 (DNA Genotek) swab. Genomic DNA were extracted from buccal swab samples using Monarch Genomic DNA Purification Kit (NEB \#T3010) following the manufacturer's instructions. Concentration of gDNA extracts were quantified using BioDrop spectrophotometer. Acceptance criteria to further process the DNA extract for genotyping, include: (1) total DNA yield $\geq 500 \mathrm{ng}$, (2) A260/280 ratio $\geq 1.75$, and (3) A260/230 ratio $\geq 1.75$.

\section{CYP2D6 Genotyping}

CYP2D6 genotyping was performed using Nala PGx Core $^{\mathrm{TM}}$, a Lab-Developed Test genotyping panel consisting of four pharmacogenes: CYP2D6, CYP2C19, CYP2C9 and SLCO1B1 (Kothary et al., 2021). CYP2D6 variants that were genotyped in this test included rs35742686, rs59421388, rs3892097, rs5030656, rs72549352, rs5030655, rs28371725, rs16947, rs1065852, rs267608319, rs769258, rs5030865, rs1135840, total copy number of intron 2 and a detection for the presence of exon 9 conversion. Genomic DNA extracts were diluted to $2 \mathrm{ng} / \mathrm{uL}$ and added as template for Nala PGx Core $^{\mathrm{TM}}$ qPCR runs on Bio-Rad CFX96 Touch $^{\mathrm{TM}}$ Real-Time PCR Detection System. CYP2D6 haplotypes, diplotypes and phenotypes were inferred by Nala Clinical Decision Support ${ }^{\mathrm{TM}}$ which is a class $A$ medical device (Health Sciences Authority, Singapore) compatible with Nala PGx Core ${ }^{T M}$ qPCR output.

\section{Measurement of Tamoxifen Metabolites}

Finger-prick blood sample was obtained using Volumetric Absorptive Microsampling (VAMS) technique. VAMS extraction was performed in methanol by sonication-assisted extraction method for 25 minutes after 2 hours of VAMS drying. Separation was carried out using Acquity UPLC BEH $C_{18}$ column $(2.1 \times 100 \mathrm{~mm} ; 1.7 \mu \mathrm{m})$, with a flow rate of $0.2 \mathrm{~mL} /$ minute, and the mobile phase gradient of 
medRxiv preprint doi: https://doi.org/10.1101/2021.06.25.21259564; this version posted June 30, 2021. The copyright holder for this preprint (which was not certified by peer review) is the author/funder, who has granted medRxiv a license to display the preprint in perpetuity.

It is made available under a CC-BY 4.0 International license .

135 formic acid $0.1 \%$ combined with formic acid $0.1 \%$ in acetonitrile for 5 minutes. The UPLC-MS/MS

136 Waters Xevo TQD Triple Quadrupole with MassLynx Software controller (Waters, Milford, USA) was

137 employed in metabolites measurement. Mass detection was carried out utilizing Triple Quadrupole

138 (TQD) with Multiple Reaction Monitoring (MRM) analysis modes and an electrospray ionization

139 source using positive mode. The method was developed in the Bioavailability and Bioequivalence

140 Laboratory of Universitas Indonesia and validated according to FDA and EMA guidelines (Maggadani

141 et al., 2021). The multiple reaction monitoring (MRM) value were set at $\mathrm{m} / \mathrm{z} 372.28>72.22$ for TAM;

$142374.29>58.22$ for END; 388.29>72.19 for $4-\mathrm{HT} ; 358.22>58.09$ for NDT; and $260.20>116.20$ for

143 propranolol as the internal standard.

144

145

146

\section{Patient Follow Up}

Patients with IM or PM CYP2D6 profile who were clinically ineligible for tamoxifen dose increase were switched to aromatase inhibitor $(n=18)$ and were not followed up further for side effects monitoring and metabolite levels changes. This group of patients were determined based on clinical judgement according to the available guidelines by The National Surgical Oncologist Organization and Ministry of Health in Indonesia (Komite Penanggulangan Kanker Nasional, n.d.), National Comprehensive Cancer Network (NCCN, 2021), and British Columbia Cancer Agency (Kennecke et al., 2006). IM or PM patients who did not have any contraindications to tamoxifen were given a recommendation to adjust its dose to $40 \mathrm{mg} /$ day $(\mathrm{n}=26$ ), while UMs and NMs remained with the normal $20 \mathrm{mg} /$ day recommended dose $(n=81)$. Tamoxifen metabolites levels in the study participants who were given $40 \mathrm{mg} /$ day of tamoxifen were measured eight weeks post dose adjustment. Endocrine symptoms which were possible side effects of tamoxifen therapy were also monitored in patients who received tamoxifen dose adjustment to $40 \mathrm{mg}$ daily using the FACT-ES questionnaire (Fallowfield et al., 1999).

\section{Data Analysis}

Data and statistical analysis were performed using Microsoft ${ }^{\oplus}$ Excel $^{\circledast}$ for Microsoft 365 and $\mathrm{R}$ version 4.0.3. Deviation from Hardy-Weinberg equilibrium was performed on the haplotype frequencies using the chi-square statistical test, where Bonferonni correction was applied to determine the $p$ value threshold for significant deviation. Analysis of Variance (ANOVA) test was used to see if metabolite levels distribution at baseline were statistically different across all metabolites, followed by a paired T-test between each pair of metabolites when significance was found. Distribution of metabolite levels before and after dose adjustment was compared using a T-test, and the same test was used to compare the distribution of metabolite levels in IMs post-dose adjustment against NMs (baseline). Concerning symptoms related to endocrine therapy post-dose adjustment on IMs were compared against NMs. Chi-square test was performed per symptom to check for the difference between the two groups.

\section{Results}

\section{Demographics of Study Participants}

177 Table 1 shows that out of the 151 participants included in the study, most of the participants were 17850 years old and below, making up $78.15 \%$ of the total respondents. This proportion was followed by 179 participants between $51-59$ years old (17.88\%). A small number of older participants with age $\geq 60$ 
medRxiv preprint doi: https://doi.org/10.1101/2021.06.25.21259564; this version posted June 30, 2021. The copyright holder for this preprint (which was not certified by peer review) is the author/funder, who has granted medRxiv a license to display the preprint in perpetuity.

It is made available under a CC-BY 4.0 International license .

years (3.97\%) was also observed. The majority of participants consisted of individuals with Chinese (33.77\%) and Javanese $(25.17 \%)$ descents. Participants with multiethnic and multiracial descents were also observed (16.56\%), followed by small numbers of other Indonesian ethnicities such as Sundanese (5.96\%), Batak (5.3\%), Betawi (3.31\%), Minang (3.31\%), Ambonese (1.32\%), and South Sumatran (1.32\%). Among these participants, $47.33 \%$ underwent lumpectomy (also known as breast conserving surgery), while $44 \%$ underwent mastectomy (total removal of breast tissue). Aside from surgical intervention, $66.67 \%$ of these participants underwent adjuvant post-operative radiotherapy and $50 \%$ underwent adjuvant chemotherapy. Respondents were mostly still in the early stage of breast cancer during the time of recruitment, with proportion as follows: stage I (27.15\%), stage lla (23.84\%), and stage Ilb (13.91\%). Participants who were enrolled to the study and were in the later stage of breast cancer were also observed, with proportion as follows: stage IIla (7.95\%), IIlb $(5.96 \%)$, and stage IV (7.95\%). About half of the study participants $(50.33 \%)$ were enrolled within 12 months after initial diagnosis of breast cancer. The other participants were enrolled within 13-24 (15.23\%), 25-36 (13.25\%), and 37-48 (9.27\%) months after initial diagnosis, with a proportion of patients who had been diagnosed for longer than four years ago (10.6\%). According to the available biopsy data, $44.37 \%$ of the participants had moderately differentiated tumors, while $27.81 \%$ and $11.92 \%$ of the participants had poorly and moderately differentiated tumors, respectively.

\section{CYP2D6 Haplotype Distribution}

All haplotypes observed were in Hardy-Weinberg equilibrium ( $p$-value $>0.005$ ). CYP2D6*10 was found to be the most abundant haplotype in the population $(0.288, n=83 / 288)$, followed by CYP2D6*36 (0.253, n=73/288). Compared to PharmGKB database of the East Asian population, *10 was lower, but *36 was much higher in this study compared to the frequency reported by the database, 0.012 (Fig. 2). The reference haplotype CYP2D6*1 was observed with frequency of 0.233 $(n=67 / 288)$, and other haplotypes were also observed with frequencies as follows: *2 $(0.128$, $\mathrm{n}=37 / 288), * 41(0.045, \mathrm{n}=13 / 288), * 5(0.021, \mathrm{n}=6 / 288), * 3(0.014, \mathrm{n}=4 / 288), * 39(0.007, \mathrm{n}=2 / 288)$, *4A $(0.007, n=2 / 288)$, and *14 $(0.003, n=1 / 288)$.

\section{CYP2D6 Diplotype Distribution}

Our study demonstrated $* 10 / * 36(0.236, n=34 / 144)$ as the most abundant diplotype in the population, followed by *1/*36 $(0.132, n=19 / 144)$ (Table 2$)$. Other diplotypes that were observed in this study with diplotype frequencies between 0.1-0.05 were as follows: $* 2 /{ }^{*} 10(0.097, n=14 / 144)$, *1/*1 (0.09, $n=13 / 144), * 2 /{ }^{*} 36(0.083, n=12 / 144), * 1 /{ }^{*} 10(0.076, n=11 / 144)$, and *10/*10 (0.065, $\mathrm{n}=9 / 144)$. Other diplotypes observed had frequencies lower than 0.05 . The list of relevant diplotypes can be found in Table 2 .

\section{CYP2D6 Phenotypes Distribution}

Our findings show that among the 150 patients genotyped, $40.67 \%$ ( $n=61 / 150)$ were IMs. This is much higher than the current known global prevalence of IMs which is between $0.4-11 \%$. The frequency of NMs observed in this study was $54 \%$ ( $n=81 / 150)$. PMs were also observed in the population at $1.33 \%$ ( $n=61 / 150$ ) (Fig. 3). Ultrarapid metabolizers were not observed among the participants in this study. Distribution of the CYP2D6 phenotypes among major ethnicities in this study's participants showed a higher proportion of IMs in Chinese $(56.86 \%, n=29 / 51$ ) compared to other ethnicities such as Javanese $(23.68 \%, n=9 / 38)$. PM was observed in the Javanese group with $2.63 \%$ frequency $(n=1)$. Ethnicities with participant counts less than 10 were grouped as others, due 
medRxiv preprint doi: https://doi.org/10.1101/2021.06.25.21259564; this version posted June 30, 2021. The copyright holder for this preprint (which was not certified by peer review) is the author/funder, who has granted medRxiv a license to display the preprint in perpetuity.

It is made available under a CC-BY 4.0 International license

225

226

227

228

229

230

231

232

233

234

235

236

237

238

239

240

241

242

243

244

245

246

247

248

249

250

251

252

253

254

255

256

257

258

259

260

261

262

263

264

265

266

267

268

269 to inefficient number of samples to conclude allele frequencies (Supplementary Table 2). Mixed races group showed $37.5 \%$ proportion of $I M(n=6 / 16)$. Among all major ethnicity groups, only Chinese ethnicity group displayed a greater proportion of IM compared to NM (Fig. 4).

\section{Tamoxifen Metabolite Concentration}

Endoxifen levels among the three metabolizers were significantly different ( $p$-value $=0.00307$, Table 3 ). The rest of the metabolites did not show any statistically significant distribution among phenotypes $(p$-value $=0.964,0.461,0.443$ for tamoxifen, 4-hydroxytamoxifen, and $\mathrm{N}$ desmethyltamoxifen, respectively). T-test performed on endoxifen levels for each phenotype pair displayed significant difference among all phenotype pairs ( $p$-value $=6.26 \times 10^{-5}, 9.12 \times 10^{-5}$, and $4.714 \times 10^{-3}$ for NM-PM, NM-IM, and IM-PM, respectively), demonstrating distinction of endoxifen levels across different phenotypes (Fig. 5). After grouping the endoxifen levels into five quintiles, it was revealed that the highest number of IMs fall into the lowest quintile while the highest number of NMs fall into the highest quintile (Supplementary Table 1).

\section{Follow Up Action Following PGx Testing}

Among 66 IM or PM participants who were given the recommendation to modify their medication based on their CYP2D6 phenotype (Fig. 6), 18 patients (27.3\%, $n=18 / 66$ ) had their medication switched to aromatase inhibitors based on clinical guidelines or certain medical procedure such as post Ovarian Function Suppression (OFS) endocrine therapy. 38 patients $(57.6 \%, n=38 / 66$ ) were recommended by their physicians to adjust their tamoxifen dosage from $20 \mathrm{mg}$ daily to $40 \mathrm{mg}$ daily, while the remaining participants who did not follow the genotype-guided recommendation either passed away or experienced recurrence, thus they had to dismiss their adjuvant therapy temporarily (15.2\%, $n=10 / 66)$.

\section{Metabolite Levels Post Dose Adjustment}

26 patients who took $40 \mathrm{mg}$ of tamoxifen daily for two months all experienced an increase in metabolite levels. After dose adjustment, the range of tamoxifen metabolites increased as follows: tamoxifen levels from $14.22-210.39 \mathrm{ng} / \mathrm{mL}$ to $80.59-254.96 \mathrm{ng} / \mathrm{mL}$; endoxifen levels from 3.17-22.97 $\mathrm{ng} / \mathrm{mL}$ to $7.68-23.36 \mathrm{ng} / \mathrm{mL}$; 4-hydroxytamoxifen levels from $1.5-9.31 \mathrm{ng} / \mathrm{mL}$ to $3.34-12.99 \mathrm{ng} / \mathrm{mL}$, and N-desmethyltamoxifen levels from 77.61-337.29 ng/mL to $236.8-501.9 \mathrm{ng} / \mathrm{mL}$ (Fig. 7). Metabolite levels before and after dose adjustment had $p$-value $<0.05$, demonstrating statistically significant differences before and after dose adjustment across all metabolites.

The metabolite levels in IMs $(n=26)$ post dose adjustment were compared against NMs $(n=81)$ as the baseline, showing indeed a significant difference between the two groups ( $p$-value $<0.05$ ) for all metabolites except endoxifen ( $p$-value $=0.4135)$. The distribution of endoxifen levels in IMs post dose adjustment $(7.68-23.36 \mathrm{ng} / \mathrm{mL}$ ) were similar to the endoxifen levels in NMs (3.55 - 34.77 $\mathrm{ng} / \mathrm{mL}$ ) at baseline (Fig. 8).

\section{Side Effects Post Dose Adjustment}

The most commonly reported treatment side effects in IMs were weight gain and mood swings, which are related to endocrine therapy. These occurred in $65.83 \%$ of participants who received 40 $\mathrm{mg}$ of tamoxifen daily ( $\mathrm{n}=17 / 26)$. Other common symptoms related to hormonal changes were also observed in participants who received $40 \mathrm{mg}$ of tamoxifen daily such as hotflush $(50 \%, n=13 / 26)$, 
medRxiv preprint doi: https://doi.org/10.1101/2021.06.25.21259564; this version posted June 30, 2021. The copyright holder for this preprint (which was not certified by peer review) is the author/funder, who has granted medRxiv a license to display the preprint in perpetuity.

It is made available under a CC-BY 4.0 International license.

270

271

272

273

274

275

276

277

278

279

280

281

282

283

284

285

286

287

288

289

290

291

292

293

294

295

296

297

298

299

300

301

302

303

304

305

306

307

308

309

310

311

312

313 cold sweats $(19.23 \%, n=5 / 26)$, night sweats $(26.92 \%, n=7 / 26)$, vaginal discharge $(42.31 \%, n=11 / 26)$, vaginal itching or irritation $(15.38 \%, n=4 / 26)$, vaginal bleeding or spotting $(23.08 \%, n=6 / 26)$, vaginal dryness $(11.54 \%, n=3 / 26)$, pain or discomfort during intercourse $(3.85 \%, n=1 / 26)$, lost interest in sex $(15.38 \%, n=4 / 26)$, breast sensitivity or tenderness $(53.85 \%, n=14 / 26)$, and irritability $(61.54 \%$, $\mathrm{n}=16 / 26)$. Other symptoms that might be related to endocrine therapy were also observed, such as lightheaded/dizziness ( $34.62 \%, n=9 / 26)$, vomiting (3.85\%, $n=1 / 26)$, headaches $(53.85 \%, n=14 / 26)$, bloating $(46.15 \%, n=12 / 26)$, and pain in joints $(50 \%, n=13 / 26)$. No post-dose adjustment participants reported diarrhea.

The most commonly reported side effect in the patient group that took $20 \mathrm{mg}$ of tamoxifen daily was mood swings, occuring in $74.19 \%$ of the respondents ( $n=23 / 31$ ), although they did not receive any treatment adjustments. Other common symptoms related to hormonal changes were also observed in NM participants such has hotflush $(35.48 \%, n=11 / 31)$, cold sweats $(12.9 \%, n=4 / 31)$, night sweats (29.03\%, $n=9 / 31)$, vaginal discharge $(38.71 \%, n=12 / 31)$, vaginal itching or irritation $(22.58 \%, n=7 / 31)$, vaginal bleeding or spotting $(16.13 \%, n=5 / 31)$, vaginal dryness $(32.26 \%, n=10 / 31)$, pain or discomfort during intercourse $(51.61 \%, n=16 / 31)$, lost interest in sex $(64.52 \%, n=20 / 31)$, breast sensitivity or tenderness $(41.94 \%, n=13 / 31)$, and irritability $(58.06 \%, n=18 / 31)$. Other symptoms that might be related to endocrine therapy were also observed, such as lightheaded/dizziness (35.48\%, $n=11 / 31$ ), vomiting $(6.45 \%, n=2 / 31)$, diarrhea $(3.23 \%, n=1 / 31)$, headaches $(29.03 \%, n=9 / 31)$, bloating $(38.71 \%$, $n=12 / 31$ ), and pain in joints $67.74 \%, n=21 / 31$ ).

T-test performed between symptoms experienced by participants receiving dose adjustment to 40 $\mathrm{mg}$ daily and participants taking $20 \mathrm{mg}$ daily resulted in two symptoms (pain or discomfort during intercourse and lost interest in sex) with statistical significance between the two groups. Other than these two symptoms, the other symptoms did not have significant difference among the two groups, indicating that dose escalation up to $40 \mathrm{mg}$ daily did not increase potential toxicity or side effects (Table 4). Thrombophlebitis, thrombosis, endometriosis, and endometrial cancer were also some of the most concerning side effects of tamoxifen (American Society of Clinical Oncology, 2009; Bergman et al., 2000), and none of these side effects were observed in the observed population.

\section{Discussion}

This study aimed to observe the distribution of CYP2D6 genotypes and phenotypes across Indonesian women diagnosed with ER+ breast cancer who were taking tamoxifen as adjuvant therapy. Our respondents were mostly of Chinese and Javanese descent. Chinese ethnicity group in this study's population showed a higher proportion of intermediate metabolizers, while the Javanese ethnicity group was dominated by normal metabolizers (Fig. 4). The proportion of IMs in Indonesian Chinese included in this study was higher than a similar study conducted on Han Chinese population, which was $45.38 \%$ (Cui et al., 2020). Ethnicity differences may play a role in contributing to the differences between the findings in this study and other similar studies conducted in different populations. Caucasians may have a higher proportion of normal metabolizers compared to other races/ethnicities though the frequencies are slightly varied depending on the geographical location where the studies were conducted (Zafra-Ceres et al., 2013; Hertz et al., 2016; Helland et al., 2017). 
medRxiv preprint doi: https://doi.org/10.1101/2021.06.25.21259564; this version posted June 30, 2021. The copyright holder for this preprint (which was not certified by peer review) is the author/funder, who has granted medRxiv a license to display the preprint in perpetuity.

It is made available under a CC-BY 4.0 International license.

314

315 Our results reported CYP2D6*10 as the most common CYP2D6 haplotype. Some studies have

316 suggested that this allele increases the risk of breast cancer recurrence for those taking tamoxifen as

317 adjuvant therapy (Kiyotani et al., 2008). A study conducted in the Han Chinese population showed

318 that the frequency of CYP2D6*10 in this population was $45.7 \%$ (Lan et al., 2018), higher than the

319 frequency of CYP2D6*10 observed in this study (28.8\%). Another important highlight was the

320 relatively high frequency of $* 36$ allele observed in this study $(0.253)$ compared to the observed

321

322

323

324

325

326

327

328

329

330

331

332

333

334

335

336

337

338

339

340

341

342

343

344

345

346

347

348

349

350

351

352

353

354

355

356

357

frequency in the PharmGKB database (0.012). Compared to other Asian population, a study conducted in Hong Kong population also recorded a relatively high frequency of CYP2D6*36 which is $34.1 \%$ (Chan et al., 2019). Although some *36 allele contributed to normal metabolizer status profile, our study observed $* 10 / * 36$ diplotype as the diplotype with highest frequency (0.236), and this diplotype translates as IM phenotype which suggested that *36 may play an important role in constructing IM phenotype profiles in Indonesian population. These findings suggested that Indonesian population might be at higher risk of experiencing ineffectiveness of tamoxifen therapy. This was also supported by the high proportion of CYP2D6 IMs (40.67\%) compared to other studies conducted in different populations (Madlensky et al., 2011). This was also much higher than the current known global prevalence of IMs which is between 0.4-11\% (Gaedigk et al., 2017). Even so, some populations also reported a higher proportion of IMs (Hertz et al., 2016), suggesting that different populations composed of various ethnicities may play a role in genetic make-up differences of CYP2D6. Compared to our result, a similar study conducted in Thailand population showed a relatively high frequency compared to the global prevalence (29.1\%), implying that East Asian population may have relatively higher frequency of IM (Sukasem et al., 2012). The frequency of NMs observed in this study (54\%) was also lower than the current known global prevalence which is between $67-90 \%$ (Gaedigk et al., 2017).

Different metabolites of tamoxifen and their levels were a predictor of tamoxifen's efficacy, especially endoxifen levels. Lower endoxifen levels in IMs may indicate lower efficacy of tamoxifen in preventing recurrence (Madlensky et al., 2011). Compared to the study conducted by Madlensky et al. (2011), the average value of endoxifen levels in IMs observed in this study was higher. The previous study observed the average endoxifen level of IMs to be $8.1 \mathrm{ng} / \mathrm{mL}$ while this study recorded an average at $9.6 \mathrm{ng} / \mathrm{mL}$. However, a study conducted in Swedish population found a range of endoxifen level between 2.3-16 ng/mL (Thorén et al., 2021), while another study conducted in Singaporean population displayed a range between $1.74-42.8 \mathrm{ng} / \mathrm{mL}$ (Lim et al., 2011). These suggested that studies conducted with similar interventions but in different populations may find different ranges of metabolite levels.

In this study, we recommended IMs and PMs to adjust their tamoxifen dosage or switch prescription to aromatase inhibitors for patients that were clinically ineligible for consumption of tamoxifen (Goetz et al., 2018). We specifically monitored patients who received tamoxifen dose adjustment to $40 \mathrm{mg}$ daily, and our results have shown that participants who received $40 \mathrm{mg}$ of tamoxifen daily all experienced a significant increase across all metabolite levels, including endoxifen levels. This suggested that increasing tamoxifen intake can elevate endoxifen levels as expected and may play a role in increasing the therapeutic effect of tamoxifen. The distribution of endoxifen level in IMs post dose adjustment were similar to the endoxifen level in NMs at the baseline, suggesting that 
medRxiv preprint doi: https://doi.org/10.1101/2021.06.25.21259564; this version posted June 30, 2021. The copyright holder for this preprint (which was not certified by peer review) is the author/funder, who has granted medRxiv a license to display the preprint in perpetuity.

It is made available under a CC-BY 4.0 International license.

increasing tamoxifen dosage to $40 \mathrm{mg}$ daily for IM participants had successfully let IM participants reach the expected endoxifen levels as observed in NMs.

Gynecological side effects similar to menopausal symptoms such as hot flushes, vaginal dryness, and endometriosis were commonly observed in patients taking tamoxifen (Mourits et al., 2001). According to the survey for endocrine symptoms in this study, most participants experienced mild to moderate degree of endocrine symptoms. Despite some of the IM respondents in this study who received dose increase reporting experiencing hot flush, no respondents reported dismissing tamoxifen intake due to the symptom. Hot flush was also commonly reported in patients taking the standard dose of tamoxifen therapy (Kligman \& Younus, 2010; Mortimer et al., 2008), which means increasing tamoxifen dose does not change side effects of the drug distinctly. Thrombophlebitis, thrombosis, endometriosis, and endometrial cancer were also some of the most concerning side effects of tamoxifen (American Society of Clinical Oncology, 2009; Bergman et al., 2000), since they fatally affect patients' quality of life and life expectancy. None of these side effects were observed in the observed population, but this might also be underestimated due to the short period of follow up on this study. Other studies who have tried to observe tamoxifen side effects occurring in patients with dose increase also concluded that increasing tamoxifen dose did not result in toxicity or shortterm increase in side effects (Hertz et al., 2016; Dezentjé et al., 2015).

These findings concluded that tamoxifen dose adjustment is beneficial enough to increase potential therapeutic effect through the increase of metabolite levels, with no fatal side effects recorded. Although CPIC guideline recommended the first course of action to switch to aromatase inhibitors, our finding demonstrated that tamoxifen dose adjustment is adequate. This is favorable due to: 1) the higher likelihood of potential side effects from aromatase inhibitors than tamoxifen (Garreau et al., 2006), 2) lower price of tamoxifen than aromatase inhibitors to allow cost-effectiveness in periodical prescriptions throughout the period of adjuvant therapy.

\section{Limitations}

One of the several limitations of this study was the subjective measurement of side effects using FACT-ES. Due to the subjective nature of answering the survey and rating each symptom, each respondent may have their own perspective on symptom intensity and severity. Another limitation of this study was the relatively short amount of follow up actions observation, which may lead to underestimating the number of certain side effects that may not immediately show up after tamoxifen therapy initiation.

\section{Conclusion}

Our study has shown a considerable proportion of CYP2D6 intermediate metabolizers $(40.67 \%)$ in Indonesian women with ER+ breast cancer consuming tamoxifen, suggesting possible ineffectiveness of tamoxifen therapy to prevent recurrence. This was also supported by the significant difference of the endoxifen levels between normal and intermediate metabolizers in our study participants. Dose adjustment of tamoxifen was proven to elevate the level of endoxifen, the metabolite responsible for the anticancer effect of tamoxifen. Increase of tamoxifen intake to $40 \mathrm{mg}$ daily in IM patients did not show any significant or fatal side effects. Given these findings, implementing pharmacogenomic testing of CYP2D6 on ER+ breast cancer women who are about to undergo adjuvant therapy with 
medRxiv preprint doi: https://doi.org/10.1101/2021.06.25.21259564; this version posted June 30, 2021. The copyright holder for this preprint (which was not certified by peer review) is the author/funder, who has granted medRxiv a license to display the preprint in perpetuity.

It is made available under a CC-BY 4.0 International license .

402

403

404

405

406

407

408

409

410

411

412

413

414

415

416

417

418

419

420

421

422

423

424

425

426

427

428

429

430

431

432

433

434

435

436

437

438

439

440

441

442

443

tamoxifen may be beneficial to avoid possible inefficacy of tamoxifen in preventing breast cancer recurrence.

\section{Future Work}

Our study has validated the need and benefit of pharmacokinetics and pharmacogenomics analysis, further follow up on the same breast cancer patient cohort is required to better understand the effect and benefits of CYP2D6 genotyping and endoxifen level measurement towards clinical outcomes such as relapse rate, disease-free survival, and overall survival. Future work may involve monitoring these patients for a longer period of duration when potential side effects were reported previously to appear (Lorizio et al., 2012). Monitoring this cohort may be useful to prove the benefit of CYP2D6 genotyping towards the clinical outcomes of tamoxifen therapy in Indonesian population.

\section{Acknowledgements}

We would like to thank SJH Initiatives and MRCCC Siloam Hospital for their major contribution in patient recruitment, notably Dismas Chaspuri, MD; Arif Winata, MD; and Rachmat Nikijuluw, MD. We would also like to extend our gratitude to The Bioavailability and Bioequivalence Laboratory of Universitas Indonesia, PT Nalagenetik Riset Indonesia, and School of Medicine and Health Sciences, Atma Jaya Catholic University of Indonesia for their support in facilitating sample processing activities. We would like to acknowledge all participants who have voluntarily provided their specimen and time to be involved in this study.

\section{Authors Contribution}

BPM, LLS, Al, YH, H, and SJH contributed to study design. KIJ, MA, and SJH contributed to patient recruitment. BPM and $G$ performed laboratory experiments. KIJ and MA were responsible for patient data management. BPM, KIJ, CM, and AI performed data analysis. KIJ and CM contributed to manuscript writing with supervision from LLS, Al, BPM, and SJH.

\section{Funding}

This research was funded by the University of Indonesia's 2019-2020 research grant. Additional research expenses were also funded by Nalagenetics Pte Ltd, Singapore and PT Nalagenetik Riset Indonesia.

\section{Conflict of Interest}

KIJ, LLS, CM, MA, G, and Al are employees of Nalagenetics Pte Ltd, Singapore.

\section{Data Availability Statement}

The data that supports the findings of this study are available as supplementary materials. Any additional data is available from the corresponding author upon reasonable request.

\section{References}

American Society of Clinical Oncology Clinical Practice Guideline Update on the Use of Pharmacologic Interventions Including Tamoxifen, Raloxifene, and Aromatase Inhibition for Breast 
medRxiv preprint doi: https://doi.org/10.1101/2021.06.25.21259564; this version posted June 30, 2021. The copyright holder for this preprint (which was not certified by peer review) is the author/funder, who has granted medRxiv a license to display the preprint in perpetuity.

It is made available under a CC-BY 4.0 International license .

444 Cancer Risk Reduction. (2009). Journal of oncology practice, 5(4), 196-199.

445 https://doi.org/10.1200/JOP.0948502

446

447

Bergman, L., Beelen, M. L., Gallee, M. P., Hollema, H., Benraadt, J., \& van Leeuwen, F. E. (2000). Risk

448

and prognosis of endometrial cancer after tamoxifen for breast cancer. Comprehensive Cancer

449 Centres' ALERT Group. Assessment of Liver and Endometrial cancer Risk following Tamoxifen. Lancet

450 (London, England), 356(9233), 881-887. https://doi.org/10.1016/s0140-6736(00)02677-5

451

452

453

Bradford L. D. (2002). CYP2D6 allele frequency in European Caucasians, Asians, Africans and their

454

455

descendants. Pharmacogenomics, 3(2), 229-243. https://doi.org/10.1517/14622416.3.2.229

456

Chan, W., Li, M. S., Sundaram, S. K., Tomlinson, B., Cheung, P. Y., \& Tzang, C. H. (2019). CYP2D6 allele

457

frequencies, copy number variants, and tandems in the population of Hong Kong. Journal of clinical

458

459

laboratory analysis, 33(1), e22634. https://doi.org/10.1002/jcla.22634

460

Chin, F. W., Chan, S. C., Abdul Rahman, S., Noor Akmal, S., \& Rosli, R. (2016). CYP2D6 Genetic

461

Polymorphisms and Phenotypes in Different Ethnicities of Malaysian Breast Cancer Patients. The

breast journal, 22(1), 54-62. https://doi.org/10.1111/tbj.12518

462

463

Cui, Y., Yan, H., Su, Y., Wang, L., Lu, T., Zhang, D., \& Yue, W. (2020). CYP2D6 Genotype-Based Dose

464

Recommendations for Risperidone in Asian People. Frontiers in pharmacology, 11, 936.

465

https://doi.org/10.3389/fphar.2020.00936

466

467

Dezentjé, V. O., Guchelaar, H. J., Nortier, J. W., van de Velde, C. J., \& Gelderblom, H. (2009). Clinical

468

implications of CYP2D6 genotyping in tamoxifen treatment for breast cancer. Clinical cancer research

469

: an official journal of the American Association for Cancer Research, 15(1), 15-21.

470

https://doi.org/10.1158/1078-0432.CCR-08-2006

471

472

Dezentjé, V. O., Opdam, F. L., Gelderblom, H., Hartigh den, J., Van der Straaten, T., Vree, R.,

Maartense, E., Smorenburg, C. H., Putter, H., Dieudonné, A. S., Neven, P., Van de Velde, C. J., Nortier,

474

J. W., \& Guchelaar, H. J. (2015). CYP2D6 genotype- and endoxifen-guided tamoxifen dose escalation

475 increases endoxifen serum concentrations without increasing side effects. Breast cancer research

476

and treatment, 153(3), 583-590. https://doi.org/10.1007/s10549-015-3562-5

477

478

Fallowfield, L. J., Leaity, S. K., Howell, A., Benson, S., \& Cella, D. (1999). Assessment of quality of life

479

in women undergoing hormonal therapy for breast cancer: validation of an endocrine symptom

480

subscale for the FACT-B. Breast cancer research and treatment, 55(2), 189-199.

481

https://doi.org/10.1023/a:1006263818115

482

483

Gaedigk, A., Sangkuhl, K., Whirl-Carrillo, M. et al. (2017). Prediction of CYP2D6 phenotype from

484

genotype across world populations. Genet Med 19, 69-76 (2017).

485

https://doi.org/10.1038/gim.2016.80

486 
medRxiv preprint doi: https://doi.org/10.1101/2021.06.25.21259564; this version posted June 30, 2021. The copyright holder for this preprint (which was not certified by peer review) is the author/funder, who has granted medRxiv a license to display the preprint in perpetuity.

It is made available under a CC-BY 4.0 International license .

487 Garreau, J. R., Delamelena, T., Walts, D., Karamlou, K., \& Johnson, N. (2006). Side effects of

488 aromatase inhibitors versus tamoxifen: the patients' perspective. American journal of surgery,

489 192(4), 496-498. https://doi.org/10.1016/j.amjsurg.2006.06.018

490

491

Goetz, M. P., Sangkuhl, K., Guchelaar, H. J., Schwab, M., Province, M., Whirl-Carrillo, M., Symmans,

492 W. F., McLeod, H. L., Ratain, M. J., Zembutsu, H., Gaedigk, A., van Schaik, R. H., Ingle, J. N., Caudle, K.

493 E., \& Klein, T. E. (2018). Clinical Pharmacogenetics Implementation Consortium (CPIC) Guideline for

494 CYP2D6 and Tamoxifen Therapy. Clinical pharmacology and therapeutics, 103(5), 770-777.

495 https://doi.org/10.1002/cpt.1007

496

497

498

Goetz, M. P., Kamal, A., \& Ames, M. M. (2008). Tamoxifen pharmacogenomics: the role of CYP2D6 as

499

a predictor of drug response. Clinical pharmacology and therapeutics, 83(1), 160-166.

500

501

https://doi.org/10.1038/sj.clpt.6100367

502

Goetz, M. P., Rae, J. M., Suman, V. J., Safgren, S. L., Ames, M. M., Visscher, D. W., Reynolds, C.,

503

Couch, F. J., Lingle, W. L., Flockhart, D. A., Desta, Z., Perez, E. A., \& Ingle, J. N. (2005).

504

Pharmacogenetics of tamoxifen biotransformation is associated with clinical outcomes of efficacy

505

and hot flashes. Journal of clinical oncology : official journal of the American Society of Clinical

Oncology, 23(36), 9312-9318. https://doi.org/10.1200/JC0.2005.03.3266

506

507

Goh, L. L., Lim, C. W., Sim, W. C., Toh, L. X., \& Leong, K. P. (2017). Analysis of Genetic Variation in

508

CYP450 Genes for Clinical Implementation. PloS one, 12(1), e0169233.

509

https://doi.org/10.1371/journal.pone.0169233

510

511

Helland, T., Henne, N., Bifulco, E., Naume, B., Borgen, E., Kristensen, V. N., Kvaløy, J. T., Lash, T. L.,

512 Alnæs, G., van Schaik, R. H., Janssen, E., Hustad, S., Lien, E. A., Mellgren, G., \& Søiland, H. (2017).

513 Serum concentrations of active tamoxifen metabolites predict long-term survival in adjuvantly

514 treated breast cancer patients. Breast cancer research : BCR, 19(1), 125.

515 https://doi.org/10.1186/s13058-017-0916-4

516

517

Hertz, D. L., Deal, A., Ibrahim, J. G., Walko, C. M., Weck, K. E., Anderson, S., Magrinat, G., Olajide, O.,

518 Moore, S., Raab, R., Carrizosa, D. R., Corso, S., Schwartz, G., Graham, M., Peppercorn, J. M., Jones, D.

519 R., Desta, Z., Flockhart, D. A., Evans, J. P., McLeod, H. L., ... Irvin, W. J., Jr (2016). Tamoxifen Dose

520 Escalation in Patients With Diminished CYP2D6 Activity Normalizes Endoxifen Concentrations

521 Without Increasing Toxicity. The oncologist, 21(7), 795-803.

522 https://doi.org/10.1634/theoncologist.2015-0480

523

524

525

526

527

528

IMS prescription data Indonesia, 2015

Kennecke, H. F., Ellard, S., O’Reilly, S., Gelmon, K. A., (2006). New guidelines for treatment of early hormone-positive breast cancer with tamoxifen and aromatase inhibitors. BC Medical Journal, $48(3)$ :

529

530 Kiyotani, K., Mushiroda, T., Sasa, M., Bando, Y., Sumitomo, I., Hosono, N., Kubo, M., Nakamura, Y., \&

531 Zembutsu, H. (2008). Impact of CYP2D6*10 on recurrence-free survival in breast cancer patients 
medRxiv preprint doi: https://doi.org/10.1101/2021.06.25.21259564; this version posted June 30, 2021. The copyright holder for this preprint (which was not certified by peer review) is the author/funder, who has granted medRxiv a license to display the preprint in perpetuity.

It is made available under a CC-BY 4.0 International license .

532 receiving adjuvant tamoxifen therapy. Cancer science, 99(5), 995-999.

533 https://doi.org/10.1111/j.1349-7006.2008.00780.x

534

535 Kligman, L., \& Younus, J. (2010). Management of hot flashes in women with breast cancer. Current

536

537

538 Komite Penanggulangan Kanker Nasional. (n.d.). Panduan Penatalaksanaan Kanker Payudara.

539

540

Retrieved from http://kanker.kemkes.go.id/guidelines/PPKPayudara.pdf

542

Kothary, A. S., Mahendra, C., Tan, M., Min Tan, E. J., Hong Yi, J. P., Gabriella, Hui Jocelyn, T. X., Haruman, J. S., Lee, C. K., Yan, B., \& Irwanto, A. (2021). Validation of a multi-gene qPCR-based pharmacogenomics panel across major ethnic groups in Singapore and Indonesia. MedRxiv.

545 Published. https://doi.org/10.1101/2021.05.10.21256948 $\mathrm{Xu}, \mathrm{B}$. (2018). The relationship between the CYP2D6 polymorphisms and tamoxifen efficacy in adjuvant endocrine therapy of breast cancer patients in Chinese Han population. International journal of cancer, 143(1), 184-189. https://doi.org/10.1002/ijc.31291 Hormone Receptor-Positive Breast Cancer. JAMA network open, 3(1), e1918160. https://doi.org/10.1001/iamanetworkopen.2019.18160 biomarker predictors of side effects from tamoxifen. Breast cancer research and treatment, 132(3), receptor-positive breast cancer. Current medicinal chemistry, 20(5), 596-604. https://doi.org/10.2174/092986713804999303 and N-Desmethyltamoxifen in Breast Cancer Patients. Drug Des Devel Ther. 2021;15:2417-2430. https://doi.org/10.2147/DDDT.S286409 concentrations, CYP2D6 genotype, and breast cancer outcomes. Clinical pharmacology and therapeutics, 89(5), 718-725. https://doi.org/10.1038/clpt.2011.32 
medRxiv preprint doi: https://doi.org/10.1101/2021.06.25.21259564; this version posted June 30, 2021. The copyright holder for this preprint (which was not certified by peer review) is the author/funder, who has granted medRxiv a license to display the preprint in perpetuity.

It is made available under a CC-BY 4.0 International license .

578 Mourits, M. J., De Vries, E. G., Willemse, P. H., Ten Hoor, K. A., Hollema, H., \& Van der Zee, A. G.

579 (2001). Tamoxifen treatment and gynecologic side effects: a review. Obstetrics and gynecology, 97(5

580 Pt 2), 855-866. https://doi.org/10.1016/s0029-7844(00)01196-0

581

582 National Comprehensive Cancer Network. (2021). Breast cancer (version 4.2021). Retrieved from

583 https://www.nccn.org/professionals/physician gls/pdf/breast.pdf

584

585

Saladores, P., Mürdter, T., Eccles, D., Chowbay, B., Zgheib, N. K., Winter, S., Ganchev, B., Eccles, B.,

586 Gerty, S., Tfayli, A., Lim, J. S., Yap, Y. S., Ng, R. C., Wong, N. S., Dent, R., Habbal, M. Z., Schaeffeler, E.,

Eichelbaum, M., Schroth, W., Schwab, M., ... Brauch, H. (2015). Tamoxifen metabolism predicts drug

588

concentrations and outcome in premenopausal patients with early breast cancer. The

589

590

pharmacogenomics journal, 15(1), 84-94. https://doi.org/10.1038/tpj.2014.34

Sukasem, C., Sirachainan, E., Chamnanphon, M., Pechatanan, K., Sirisinha, T., Ativitavas, T.,

592 Panvichian, R., Ratanatharathorn, V., Trachu, N., \& Chantratita, W. (2012). Impact of CYP2D6

593

polymorphisms on tamoxifen responses of women with breast cancer: a microarray-based study in

594

Thailand. Asian Pacific journal of cancer prevention : APJCP, 13(9), 4549-4553.

595

https://doi.org/10.7314/apicp.2012.13.9.4549

596

Thorén, L., Lindh, J. D., Ackehed, G., Kringen, M. K., Hall, P., Bergh, J., Molden, E., Margolin, S., \&

598

Eliasson, E. (2021). Impairment of endoxifen formation in tamoxifen-treated premenopausal breast

599 cancer patients carrying reduced-function CYP2D6 alleles. British journal of clinical pharmacology,

600 87(3), 1243-1252. https://doi.org/10.1111/bcp.14500

601

602

Teh, L. K., Ismail, R., Yusoff, R., Hussein, A., Isa, M. N., \& Rahman, A. R. (2001). Heterogeneity of the

603 CYP2D6 gene among Malays in Malaysia. Journal of clinical pharmacy and therapeutics, 26(3), 205-

\begin{tabular}{|c|c|c|}
\hline Age & $n$ & $\%$ \\
\hline$<40$ & 23 & $15.33 \%$ \\
\hline
\end{tabular}


medRxiv preprint doi: https://doi.org/10.1101/2021.06.25.21259564; this version posted June 30, 2021. The copyright holder for this preprint (which was not certified by peer review) is the author/funder, who has granted medRxiv a license to display the preprint in perpetuity.

It is made available under a CC-BY 4.0 International license .

\begin{tabular}{|c|c|c|}
\hline $40-49$ & 88 & $58.67 \%$ \\
\hline $50-59$ & 33 & $22.00 \%$ \\
\hline$>59$ & 6 & $4.00 \%$ \\
\hline \multicolumn{3}{|l|}{ Menopausal status } \\
\hline Premenopausal & 54 & $36.00 \%$ \\
\hline Post-menopausal & 96 & $64.00 \%$ \\
\hline \multicolumn{3}{|l|}{ Menarche } \\
\hline $7-11$ years old & 24 & $16.00 \%$ \\
\hline $12-13$ years old & 83 & $55.33 \%$ \\
\hline$>13$ years old & 37 & $24.67 \%$ \\
\hline NA* & 6 & $4.00 \%$ \\
\hline \multicolumn{3}{|l|}{ Race } \\
\hline Ambon & 2 & $1.32 \%$ \\
\hline Batak & 8 & $5.30 \%$ \\
\hline Betawi & 5 & $3.31 \%$ \\
\hline Chinese & 51 & $33.77 \%$ \\
\hline Javanese & 38 & $25.17 \%$ \\
\hline Minangkabau & 5 & $3.31 \%$ \\
\hline Palembang & 2 & $1.32 \%$ \\
\hline Sunda & 9 & $5.96 \%$ \\
\hline Mixed races & 25 & $16.56 \%$ \\
\hline NA* & 6 & $3.97 \%$ \\
\hline \multicolumn{3}{|l|}{$\begin{array}{l}\text { Past Breast Cancer } \\
\text { Treatment }\end{array}$} \\
\hline Lumpectomy & 7 & $4.67 \%$ \\
\hline Lumpectomy, chemoterapy & 2 & $1.33 \%$ \\
\hline Lumpectomy, radiotherapy & 34 & $22.67 \%$ \\
\hline $\begin{array}{l}\text { Lumpectomy, } \\
\text { chemotherapy, } \\
\text { radiotherapy }\end{array}$ & 23 & $15.33 \%$ \\
\hline Mastectomy & 18 & $12.00 \%$ \\
\hline
\end{tabular}


medRxiv preprint doi: https://doi.org/10.1101/2021.06.25.21259564; this version posted June 30, 2021. The copyright holder for this preprint (which was not certified by peer review) is the author/funder, who has granted medRxiv a license to display the preprint in perpetuity.

It is made available under a CC-BY 4.0 International license .

\begin{tabular}{|c|c|c|}
\hline Mastectomy, chemoterapy & 16 & $10.67 \%$ \\
\hline Mastectomy, radiotherapy & 5 & $3.33 \%$ \\
\hline $\begin{array}{l}\text { Mastectomy, radiotherapy, } \\
\text { chemoterapy }\end{array}$ & 25 & $16.67 \%$ \\
\hline $\begin{array}{l}\text { Mastectomy, lumpectomy, } \\
\text { radiotherapy, } \\
\text { chemotherapy }\end{array}$ & 2 & $1.33 \%$ \\
\hline Radiotherapy & 9 & $6.00 \%$ \\
\hline Chemotherapy & 2 & $1.33 \%$ \\
\hline $\begin{array}{l}\text { Radiotherapy, } \\
\text { chemotherapy }\end{array}$ & 5 & $3.33 \%$ \\
\hline NA* & 2 & $1.33 \%$ \\
\hline \multicolumn{3}{|l|}{ Stage } \\
\hline ST 0 & 0 & $0 \%$ \\
\hline ST I & 34 & $22.67 \%$ \\
\hline ST ॥A & 48 & $32.00 \%$ \\
\hline ST ॥B & 17 & $11.33 \%$ \\
\hline ST IIIA & 9 & $6.00 \%$ \\
\hline ST IIIB & 11 & $7.33 \%$ \\
\hline ST IIIC & 2 & $1.33 \%$ \\
\hline ST IV & 12 & $8.00 \%$ \\
\hline NA* & 17 & $11.33 \%$ \\
\hline \multicolumn{3}{|l|}{$\begin{array}{l}\text { Time Recruited from } \\
\text { Diagnosis (Months) }\end{array}$} \\
\hline $1-12$ & 76 & $50.33 \%$ \\
\hline $13-24$ & 23 & $15.23 \%$ \\
\hline $25-36$ & 20 & $13.25 \%$ \\
\hline $37-48$ & 14 & $9.27 \%$ \\
\hline$>48$ & 16 & $10.60 \%$ \\
\hline$N A^{*}$ & 1 & $0.66 \%$ \\
\hline \multicolumn{3}{|l|}{$\underline{\text { Tumor Grade }}$} \\
\hline Well differentiated / Grade & 18 & $11.92 \%$ \\
\hline
\end{tabular}


medRxiv preprint doi: https://doi.org/10.1101/2021.06.25.21259564; this version posted June 30, 2021. The copyright holder for this preprint (which was not certified by peer review) is the author/funder, who has granted medRxiv a license to display the preprint in perpetuity.

It is made available under a CC-BY 4.0 International license .

\begin{tabular}{|l|r|r|}
\hline 1 & & \\
\hline $\begin{array}{l}\text { Moderately differentiated / } \\
\text { Grade 2 }\end{array}$ & 67 & $44.37 \%$ \\
\hline $\begin{array}{l}\text { Poorly differentiated / } \\
\text { Grade 3 }\end{array}$ & 42 & $27.81 \%$ \\
\hline NA* & 23 & $15.33 \%$ \\
\hline
\end{tabular}

*NA: data not available

621

Table 2. CYP2D6 diplotype frequencies observed

\begin{tabular}{|l|r|r|r|}
\hline Diplotype & Phenotype & Counts (N total = 144) & Frequency \\
\hline$* 10 / * 36$ & Intermediate Metabolizer & 34 & 0.236 \\
\hline$* 1 / * 36$ & Normal Metabolizer & 19 & 0.132 \\
\hline$* 2 / * 10$ & Normal Metabolizer & 14 & 0.097 \\
\hline$* 1 / * 1$ & Normal Metabolizer & 13 & 0.090 \\
\hline$* 2 / * 36$ & Normal Metabolizer & 12 & 0.083 \\
\hline$* 1 / * 10$ & Normal Metabolizer & 11 & 0.076 \\
\hline$* 10 / * 10$ & Normal Metabolizer & 9 & 0.065 \\
\hline Others^ & & 41 & 0.222 \\
\hline
\end{tabular}

^Other diplotypes were observed with frequency less than 0.05 , these diplotypes were $* 1 / * 2$,

*36/*41, *1/*41, *10/*41, *1/*5, *2/*2, *3/*36, *5/*10, *5/*41, *1/*3, *1/*4A, *14/*36, *2/*3,

$* 2 / * 39, * 2 / * 41, * 36 / * 39$, and $* 4 \mathrm{~A} / * 10$

Table 3. Summary of metabolite levels in relation to CYP2D6 metabolizer profiles

\begin{tabular}{|c|c|c|c|c|c|}
\hline \multirow{2}{*}{$\begin{array}{c}\text { CYP2D6 } \\
\text { Phenotype }\end{array}$} & \multicolumn{4}{|c|}{ Concentration (ng/mL) } \\
\cline { 3 - 6 } & & Tamoxifen & Endoxifen & 40H-tam & ND-tam \\
\hline \multirow{2}{*}{$\begin{array}{c}\text { Normal } \\
\text { Metabolizer } \\
\text { (N = 81) }\end{array}$} & Mean & 82.30 & 13.17 & 3.30 & 224.86 \\
\cline { 2 - 6 } & SD & 35.21 & 6.62 & 1.46 & 56.83 \\
\cline { 2 - 6 } & Median & 77.46 & 11.98 & 3.07 & 240.59 \\
\hline
\end{tabular}


medRxiv preprint doi: https://doi.org/10.1101/2021.06.25.21259564; this version posted June 30, 2021. The copyright holder for this preprint (which was not certified by peer review) is the author/funder, who has granted medRxiv a license to display the preprint in perpetuity.

It is made available under a CC-BY 4.0 International license .

\begin{tabular}{|c|c|c|c|c|c|c|c|}
\hline & Range & $\begin{array}{l}31.22- \\
170.82\end{array}$ & $3.55-34.77$ & \multicolumn{2}{|c|}{$1.5-7.66$} & \multicolumn{2}{|c|}{$\begin{array}{l}80.63- \\
321.88\end{array}$} \\
\hline \multirow{4}{*}{$\begin{array}{l}\text { Intermediate } \\
\text { Metabolizer } \\
(N=61)\end{array}$} & Mean & 85.62 & 9.59 & \multicolumn{2}{|c|}{3.60} & \multicolumn{2}{|c|}{233.70} \\
\hline & SD & 37.20 & 4.35 & \multicolumn{2}{|c|}{1.67} & \multicolumn{2}{|c|}{58.01} \\
\hline & Median & 81.72 & 8.33 & \multicolumn{2}{|c|}{3.27} & \multicolumn{2}{|c|}{241.55} \\
\hline & Range & $\begin{array}{l}14.22- \\
210.39\end{array}$ & $3.17-22.97$ & \multicolumn{2}{|c|}{$1.5-9.31$} & \multicolumn{2}{|c|}{$\begin{array}{l}77.61- \\
337.29\end{array}$} \\
\hline \multirow{4}{*}{$\begin{array}{l}\text { Poor } \\
\text { Metabolizer } \\
(N=2)\end{array}$} & Mean & 91.49 & 4.52 & \multicolumn{2}{|c|}{3.24} & \multicolumn{2}{|c|}{276.45} \\
\hline & SD & 33.93 & 0.83 & \multicolumn{2}{|c|}{0.26} & \multicolumn{2}{|c|}{90.44} \\
\hline & Median & 91.49 & 4.52 & \multicolumn{2}{|c|}{3.24} & \multicolumn{2}{|c|}{276.45} \\
\hline & Range & $67.49-115.48$ & $3.94-5.11$ & \multicolumn{2}{|c|}{$3.06-3.43$} & \multicolumn{2}{|c|}{$212.5-340.41$} \\
\hline \multicolumn{2}{|c|}{$p$-value (ANOVA) } & 0.964 & $0.00307^{*}$ & \multicolumn{2}{|c|}{0.461} & \multicolumn{2}{|c|}{0.443} \\
\hline \multicolumn{8}{|c|}{$\begin{array}{l}\text { Table 4. Number and percentage of patient responses related to adverse events in FACT-ES post } \\
\text { eight weeks after dose adjustment. *Statistically significant } p \text {-value was observed }\end{array}$} \\
\hline \multirow{2}{*}{\multicolumn{2}{|c|}{ Symptoms }} & \multicolumn{2}{|c|}{$\begin{array}{l}\text { NM participants who } \\
\text { received } 20 \mathrm{mg} \text { of } \\
\text { tamoxifen daily }(\mathrm{N}=31)\end{array}$} & \multicolumn{3}{|c|}{$\begin{array}{l}\text { IM participants who } \\
\text { received } 40 \mathrm{mg} \text { of } \\
\text { tamoxifen daily }(\mathrm{N}=22)\end{array}$} & \multirow[t]{2}{*}{$p$-value } \\
\hline & & $\begin{array}{l}\text { Patients } \\
\text { reported } \\
\text { side effect } \\
\text { (n) }\end{array}$ & $\begin{array}{l}\text { Patients } \\
\text { reported } \\
\text { side effect } \\
\text { (\%) }\end{array}$ & $\begin{array}{l}\text { Patients } \\
\text { reported } \\
\text { side effect } \\
\text { (n) }\end{array}$ & $\begin{array}{l}\text { Pati } \\
\text { repc } \\
\text { side } \\
\text { (\%) }\end{array}$ & $\begin{array}{l}\text { ts } \\
\text { fect }\end{array}$ & \\
\hline \multicolumn{2}{|l|}{ Hot Flushes } & 11 & $35.48 \%$ & 13 & \multicolumn{2}{|c|}{$50.00 \%$} & 0.269361 \\
\hline \multicolumn{2}{|l|}{ Cold Sweats } & 4 & $12.90 \%$ & 5 & \multicolumn{2}{|c|}{$19.23 \%$} & 0.717648 \\
\hline \multicolumn{2}{|l|}{ Night sweats } & 9 & $29.03 \%$ & 7 & \multicolumn{2}{|c|}{$26.92 \%$} & 0.86249 \\
\hline Vaginal discha & & 12 & $38.71 \%$ & 11 & & & 0.777297 \\
\hline Vaginal itching & itation & 7 & $22.58 \%$ & 4 & & & 0.492987 \\
\hline Vaginal bleedi & r spotting & 5 & $16.13 \%$ & 6 & & & 0.507122 \\
\hline
\end{tabular}


medRxiv preprint doi: https://doi.org/10.1101/2021.06.25.21259564; this version posted June 30, 2021. The copyright holder for this preprint (which was not certified by peer review) is the author/funder, who has granted medRxiv a license to display the preprint in perpetuity.

It is made available under a CC-BY 4.0 International license .

\begin{tabular}{|c|c|c|c|c|c|}
\hline Vaginal dryness & 10 & $32.26 \%$ & 3 & $11.54 \%$ & 0.063252 \\
\hline $\begin{array}{l}\text { Pain or discomfort with } \\
\text { intercourse* }\end{array}$ & 16 & $51.61 \%$ & 1 & $3.85 \%$ & $8.48 \times 10^{-5 *}$ \\
\hline Lost interest in sex & 20 & $64.52 \%$ & 4 & $15.38 \%$ & $0.005461^{*}$ \\
\hline Weight gain & 20 & $64.52 \%$ & 17 & $65.38 \%$ & 1 \\
\hline Lightheaded (dizzy) & 11 & $35.48 \%$ & 9 & $34.62 \%$ & 1 \\
\hline Vomiting & 2 & $6.45 \%$ & 1 & $3.85 \%$ & 1 \\
\hline Diarrhea & 1 & $3.23 \%$ & 0 & $0.00 \%$ & 1 \\
\hline Headaches & 9 & $29.03 \%$ & 14 & $53.85 \%$ & 0.057089 \\
\hline Bloating & 12 & $38.71 \%$ & 12 & $46.15 \%$ & 0.571608 \\
\hline Breast sensitivity/tenderness & 13 & $41.94 \%$ & 14 & $53.85 \%$ & 0.371093 \\
\hline Mood swings & 23 & $74.19 \%$ & 17 & $65.38 \%$ & 0.470842 \\
\hline Irritable & 18 & $58.06 \%$ & 16 & $61.54 \%$ & 0.791337 \\
\hline Pain in joints & 21 & $67.74 \%$ & 13 & $50.00 \%$ & 0.173783 \\
\hline
\end{tabular}

634 adjustment and NMs who took the standard dose

635

636 Figures

637 
medRxiv preprint doi: https://doi.org/10.1101/2021.06.25.21259564; this version posted June 30, 2021. The copyright holder for this preprint (which was not certified by peer review) is the author/funder, who has granted medRxiv a license to display the preprint in perpetuity.

It is made available under a CC-BY 4.0 International license .

638

639

640

641

642

643

644

645
Patients fulfilling the inclusion criteria

$\mathrm{n}=151$

Patients underwent CYP2D6 genotyping and tamoxifen metabolites were checked $\mathrm{n}=150$

Given recommendation to increase dosage ( $40 \mathrm{mg}$ daily) of

tamoxifen or switch to aromatase inhibitor (according to CPIC) $n=56$

$\downarrow$

tamoxifen metabolites were measured 8 weeks post dose increase

for patients with tamoxifen dose adjustment

$n=26$

\section{Fig.1 | Research flow diagram.}

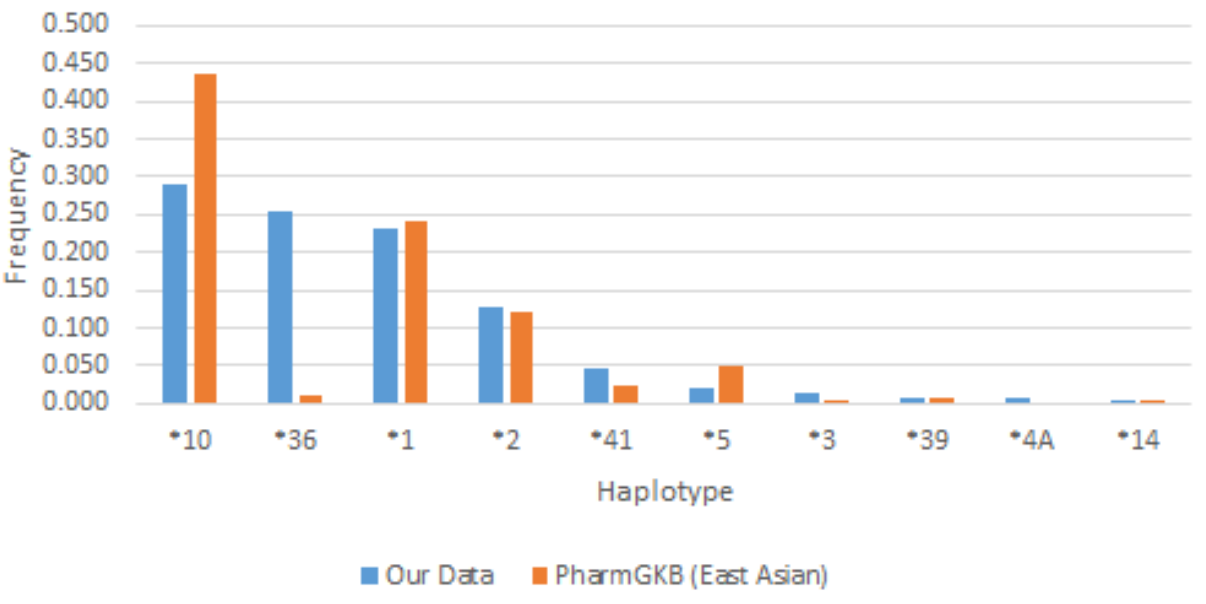

Fig.2 | Distribution of haplotype frequencies among Indonesian breast cancer patients. $n=288$
Extensive/Ultrarapid Metabolizer

$n=81$

continue taking normal dosage

(20 mg daily) of tamoxifen

$n=81$ 
medRxiv preprint doi: https://doi.org/10.1101/2021.06.25.21259564; this version posted June 30, 2021. The copyright holder for this preprint (which was not certified by peer review) is the author/funder, who has granted medRxiv a license to display the preprint in perpetuity.

It is made available under a CC-BY 4.0 International license .

649

650

651

652

653

654

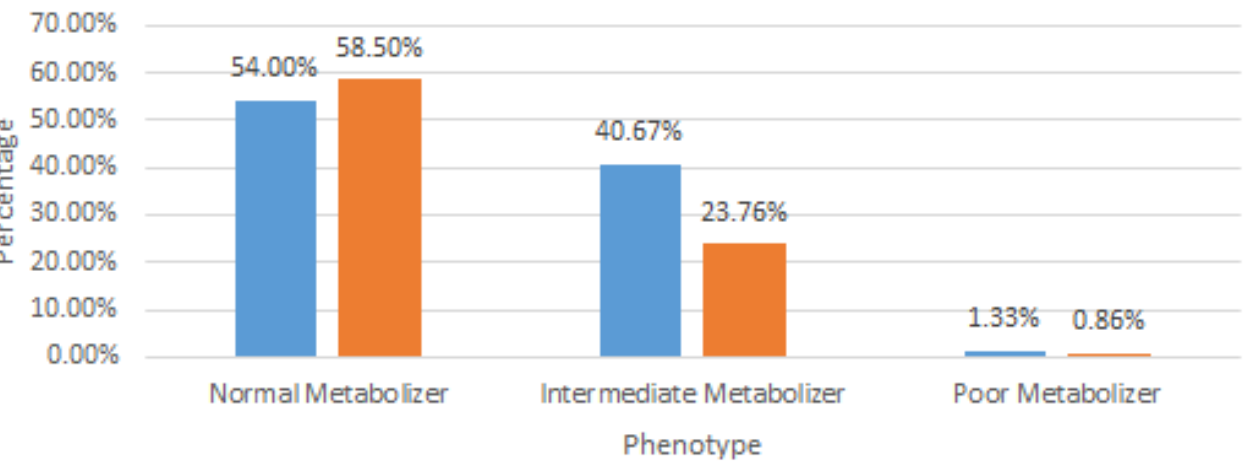

Fig.3 | Distribution of phenotype frequencies among Indonesian breast cancer patients. $n=144$

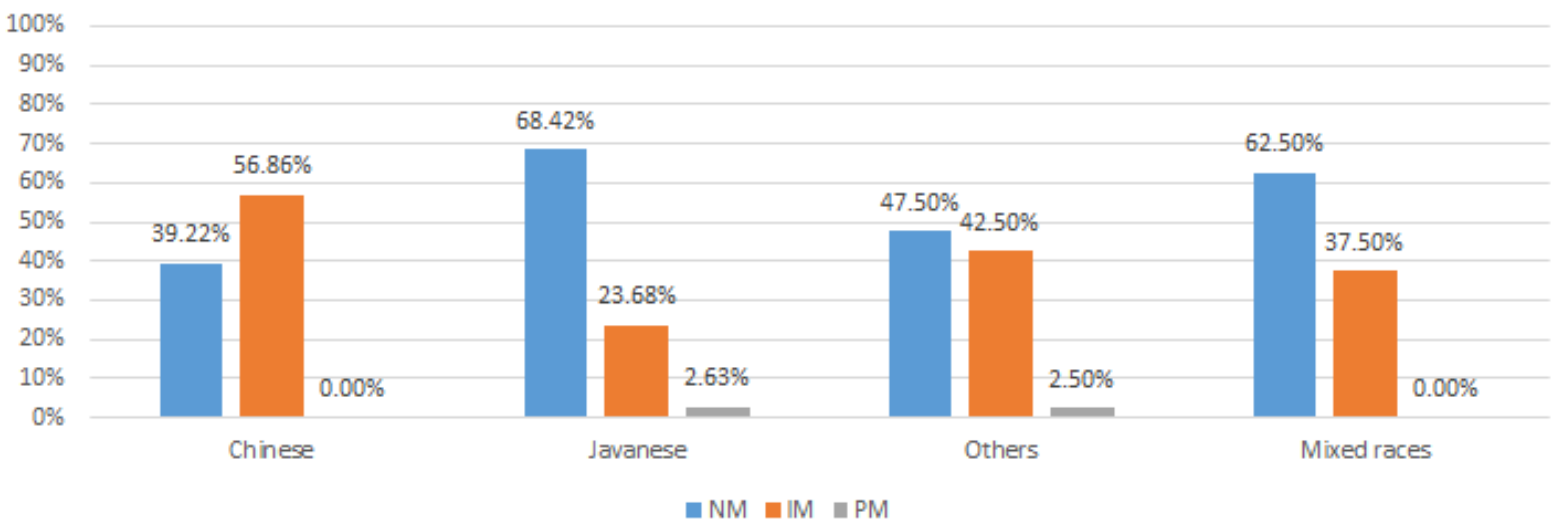

Fig.4 | Distribution of phenotype frequencies per major ethnicity among Indonesian breast cancer patients. $n=151$

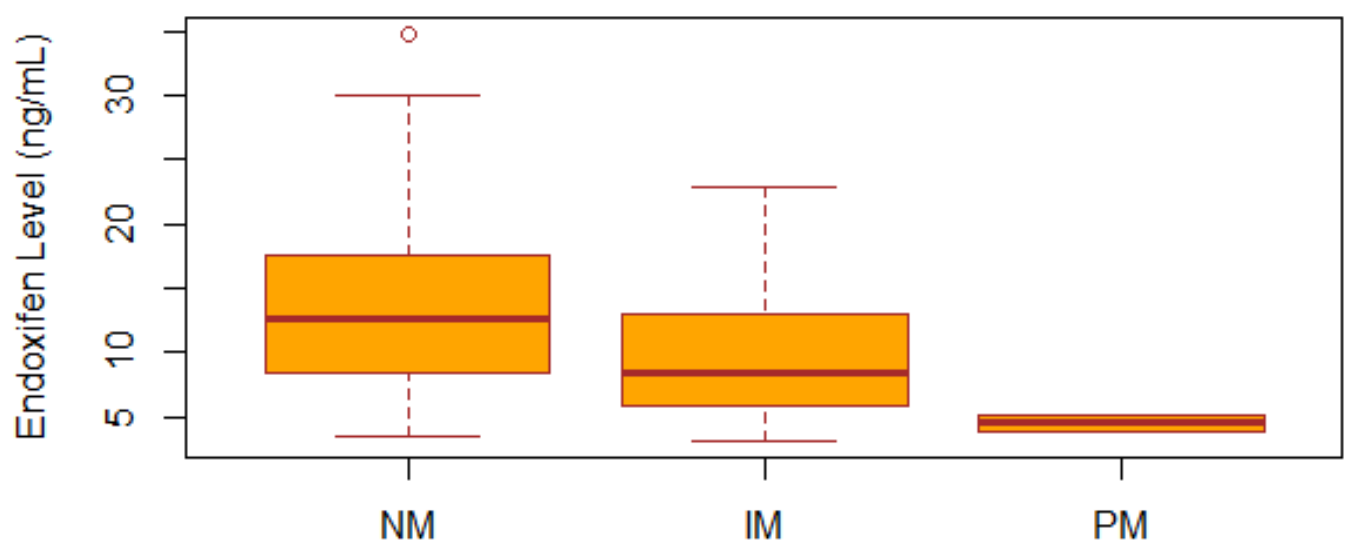

Phenotype 
medRxiv preprint doi: https://doi.org/10.1101/2021.06.25.21259564; this version posted June 30, 2021. The copyright holder for this preprint (which was not certified by peer review) is the author/funder, who has granted medRxiv a license to display the preprint in perpetuity.

It is made available under a CC-BY 4.0 International license .

656

657

658

659

660

a.

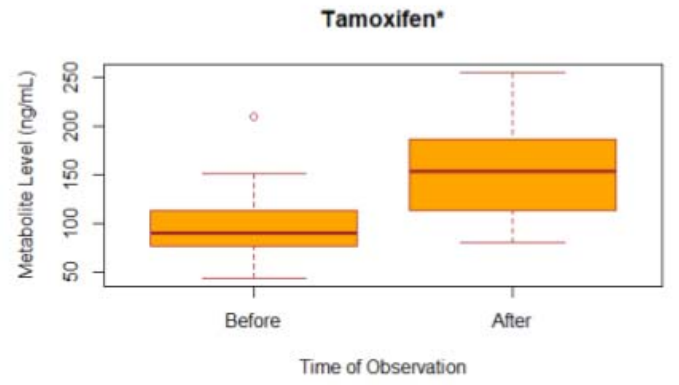

c.

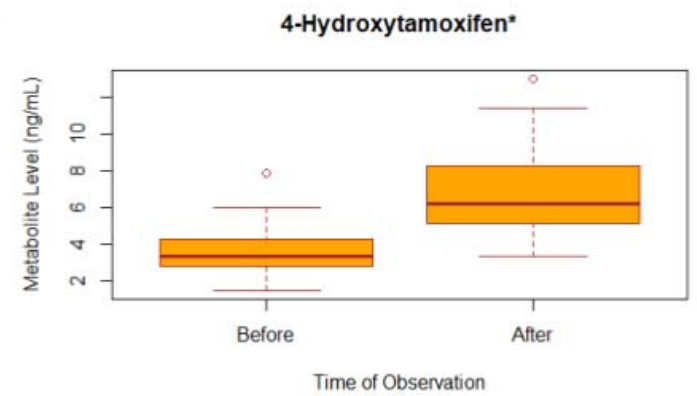

b.

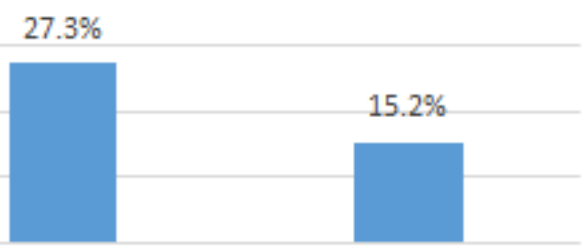

$40 \mathrm{mg}$ of tamaxifen

Changed to aromatase inhibitor

Others

Follow Up Actions

Fig.6 | Distribution of the different follow up actions selected by doctors after patient's CYP2D6 profile was characterized through genetic testing. $n=66$

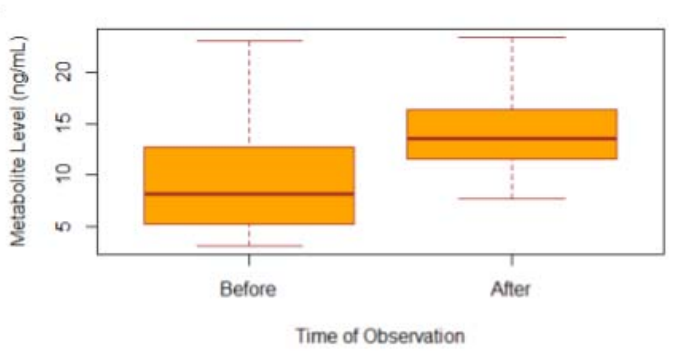

d.

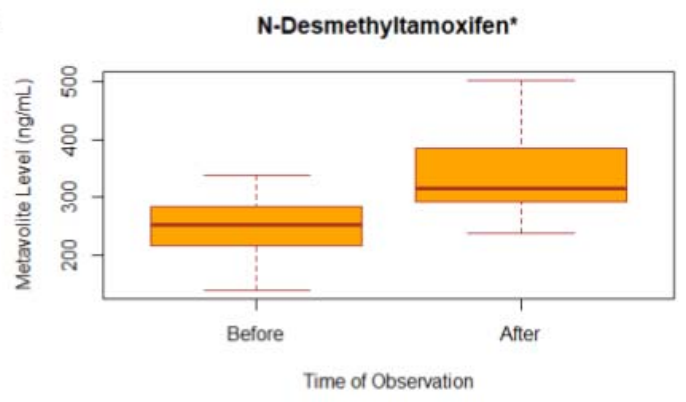

Fig.7 | Metabolite levels before and after dose adjustment for IM patients. a.) Tamoxifen, b.) endoxifen, c.) 4-hydroxytamoxifen, d.) $\mathrm{N}$-desmethyltamoxifen. *Statistically significant $p$-values were observed between metabolites before and after dose adjustment, $n=26$ 
medRxiv preprint doi: https://doi.org/10.1101/2021.06.25.21259564; this version posted June 30, 2021. The copyright holder for this preprint (which was not certified by peer review) is the author/funder, who has granted medRxiv a license to display the preprint in perpetuity.

It is made available under a CC-BY 4.0 International license .

671

672

673

674

675

676

\section{7}

678

679

680 a.

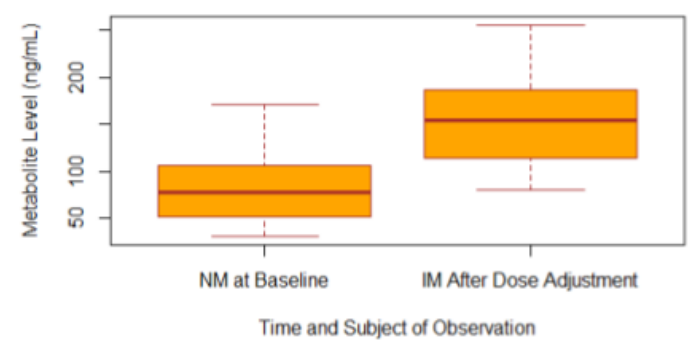

c.

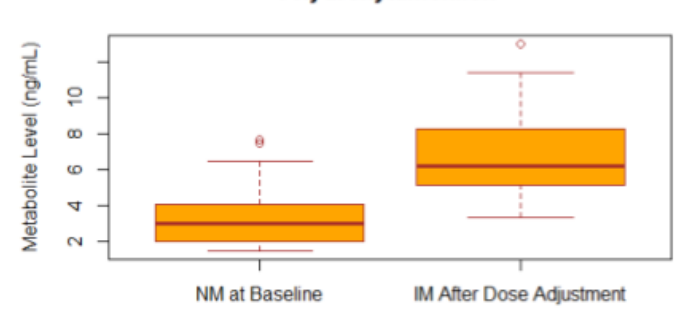

Time and Subject of Observation

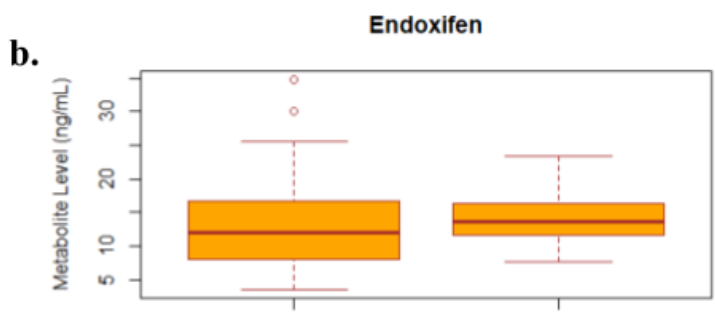

NM at Baseline IM After Dose Adjustment

Time and Subject of Observation

d.

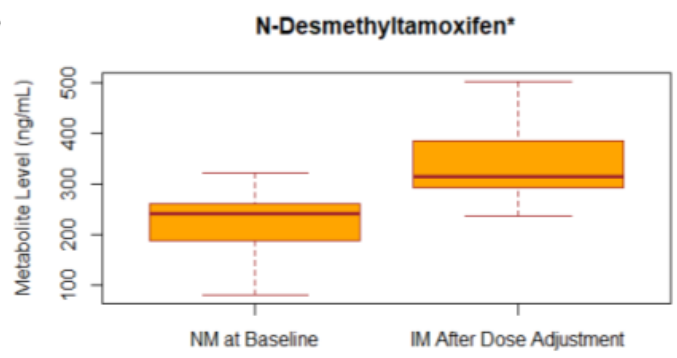

Time and Subject of Observation

Fig.8 | Metabolite levels in IMs after dose adjustment compared to NMs at the baseline. a.)

Tamoxifen, b.) endoxifen, c.) 4-hydroxytamoxifen, d.) N-desmethyltamoxifen. *Statistically significant $p$-values were observed, $n=81$ (NMs), $n=26$ (IMs). Endoxifen levels in IMs post dose adjustment were statistically similar to NMs at the baseline.

\section{Supplementary}

Supplementary Table 1. Number of NMs and IMs in each quintile group of endoxifen measured at baseline.

\begin{tabular}{|l|l|l|l|}
\hline Quintiles & \multicolumn{1}{|c|}{ NMs } & \multicolumn{1}{c|}{ IMs } & \multicolumn{1}{c|}{ PMs } \\
\hline Q1 & 8 & 17 & 2 \\
\hline Q2 & 12 & 12 & 0 \\
\hline Q3 & 19 & 11 & 0 \\
\hline Q4 & 15 & 12 & 0 \\
\hline Q5 & 23 & 5 & 0 \\
\hline
\end{tabular}

681

682 Supplementary Table 2. Number of participants in each ethnicity observed. $n=150$

\begin{tabular}{|l|l|}
\hline \multicolumn{1}{|c|}{ Ethnicity } & \multicolumn{1}{|c|}{$\mathbf{n}$} \\
\hline Chinese & 51 \\
\hline Javanese & 38 \\
\hline
\end{tabular}


medRxiv preprint doi: https://doi.org/10.1101/2021.06.25.21259564; this version posted June 30, 2021. The copyright holder for this preprint (which was not certified by peer review) is the author/funder, who has granted medRxiv a license to display the preprint in perpetuity. It is made available under a CC-BY 4.0 International license .

\begin{tabular}{|c|c|c|}
\hline \multirow{15}{*}{ Others } & Ambon & 2 \\
\hline & Batak & 8 \\
\hline & Betawi & 5 \\
\hline & Makassar & 1 \\
\hline & Manado & 1 \\
\hline & Melayu & 1 \\
\hline & Minangkabau & 5 \\
\hline & Nias & 1 \\
\hline & Padang & 1 \\
\hline & Palembang & 2 \\
\hline & West Sumatera & 1 \\
\hline & Sunda & 9 \\
\hline & Timor Leste & 1 \\
\hline & Tolaki / Sulawesi & 1 \\
\hline & Toraja & 1 \\
\hline \multicolumn{2}{|l|}{ Multiethnic } & 16 \\
\hline$N A^{*}$ & & 6 \\
\hline
\end{tabular}

*NA: data not available

684 